\title{
Crafting the society of control: Exploring Scottish child welfare policy in a neoliberal context
}

David McKendrick Glasgow Caledonian University, United Kingdom

\begin{abstract}
INTRODUCTION: This article explores contemporary Scottish child welfare policy and locates it in a neoliberal context. The existing national practice model known by the acronym GIRFEC (Getting it Right for Every Child) has been a feature of policy and legislation since early 2000. Its latest iteration is notable for two developments, one being the change in the threshold for state intervention in family life to the notion of wellbeing and secondly, the appointment of a state guardian (known as the named person scheme) for every child in Scotland.

METHOD: Drawing from the concept of late modernity (Parton, 2006), I argue that these advances constitute a net widening approach that seeks to universalise state involvement in family life. The concept of the society of control (Deleuze, 1992) is utilised as a method of exploring how the named person scheme can be viewed as a universal surveillance mechanism which seeks to preserve and promote neoliberal hegemony.

CONCLUSION: In the Scottish context the named person scheme is a vehicle for neoliberal state control. The scheme is underpinned by notions of normative compliance resulting in social work practice becoming distanced from its social change agenda, instead working on families rather than with families.
\end{abstract}

KEYWORDS: GIRFEC, named persons, neoliberalism, children and families, late modernity

\section{Introduction}

Although part of the United Kingdom, Scotland has retained a unique social work identity (Brodie, Nottingham \& Plunkett, 2006). Its services to children and young people in particular demonstrate a trajectory that differs from services in England and the rest of Great Britain (McAra \& McVie, 2007). Since the landmark Kilbrandon report, Scottish child welfare approaches have followed the lead of Scandinavian services much more closely than their English counterparts. McGhee and Waterhouse, (2010) describe Kilbrandon as "an innovation in Scottish policy ushering in a distinctive child welfare institution, the children's hearings" (p.1091).
Initially set up in May 1960 the committee chaired by Lord Kilbrandon addressed the issue of juvenile delinquency from a liberal humanist standpoint. The Kilbrandon committee concerned itself with the issue of juvenile delinquency aiming to explore its causes and to consider the most effective ways of preventing young people and their families from becoming involved with the state. One of the aims of the committee was to develop alternative methods of intervention that would emphasise the importance of the views of the children and parents as central to the relationship between the state and the family. Kilbrandon promoted a welfarist approach which considered the needs of the children and their families in the context
AOTEAROA

NEW ZEALAND SOCIAL WORK 28(3), 37-46.

CORRESPONDENCE TO:

David McKendrick David.McKendrick@ gcu.ac.uk 
of their emotional, social and personal environment. Kilbrandon argued that to tackle delinquency, a requirement existed to develop a more holistic understanding of the issues faced by the child (Smith \& Whyte, 2008). To develop such an understanding Kilbrandon argued for qualified professionals to work with children and their families to listen to and understand the unique social and personal aspects of the child's life. In particular, Kilbrandon identified a relationship between the structural disadvantage inherent in poverty and an increased propensity for delinquency in childhood. This welfarist approach has remained a central aspect of Scottish policy and echoes throughout much of the legislation for children and families as well as other areas of social work activity (McAra \& McVie, 2007).

Kilbrandon's most visible and enduring legacy, the children's hearing system, was influenced by approaches prevalent in Scandinavia. The Scottish Children Reporters Administration has consistently advocated the benefits of exploring the reasons for the child's referral to understand and contextualise the needs as well as the deeds of the child. Central to this process has been the importance given to the child's interpretation of their circumstances. McAra and McVie (2007) argue that the hearing system's emphasis on exactly these welfare principles makes it unique to Scottish society and supports the integral functions of need and deed in coming to a decision about the child. Smith and Whyte, (2008), emphasise the importance and the uniqueness of social pedagogy as a tenet of the Kilbrandon report. Social pedagogy emphasises the importance of a trusting and supportive relationship between professionals and families focusing on the influence of the internal and external experiences children and families have to endure. In order to explore fully the unique experiences of children and families, professionals require an appreciation of the social, political and cultural intersections and entanglements that constitute the peculiar complexities of family life.
The Children (Scotland) Act 1995 continued in this vein, with the importance of prevention and diversion from statutory services given particular emphasis (McGhee \& Waterhouse, 2011). The 1995 Act enshrined the no order principle placing a responsibility on local authorities and the Children's Hearing system to work in a voluntary capacity with children and their families. This principle requires the hearing to impose compulsory measures of care only if all other attempts to work with the family have failed. As I will go on to discuss below, the development of the named person scheme from 2014 forms an additional part of the GIRFEC policy (Scottish Government, 2016c) creating the role of a state guardian for every child up to the age of eighteen. The scheme aims to support families should they wish to access public services, but has resulted in an erosion of the welfarist principles that were of such importance to Kilbrandon. A variety of new terminology has simultaneously entered the lexicon that de-emphasises the influence of wider social political and economic factors on children's lives, replacing it with a more personalised discourse that sees a greater emphasis placed on individuality and personal attainment (Gilbert, 2013). The idea of wellbeing has supplanted the notion of welfare and Scottish social work policy has moved to a more individualised series of interactions with children and their families. I will demonstrate that this is a key principle of neoliberalism, one that deliberately obscures wider structural influences on children and their families by emphasising a more individualised response based on the particular circumstances of the child and their family.

This article will explore in depth a particular element of the Getting It Right For Every Child (GIRFEC) legislation, the named persons scheme (Scottish Government, 2016b). GIRFEC is Scotland's legislation to protect and support children. It is of interest to note that the GIRFEC approach which has existed in policy since the early 2000s has only became law in 
March 2014. The named person legislation is currently being redrafted after the Scottish Supreme Court found that it breached aspects of data protection law. Its aim is to ensure that all Scottish children receive the help and support that they need from either universal services, such as health and education or more specialised services such as social work. GIRFEC utilises a common assessment approach that promotes inter agency working and emphasises the requirement to place the child at the centre of any planning or practical activities that take place. The named person scheme aims to complement the Getting it Right approach by providing all children in Scotland with a named first point of contact should they or their family feel they need it (Scottish Government, 2016,b). GIRFEC and the named person scheme provide the framework for the state's support and intervention with the Scotland's children and their families. While both are developed with the stated aim of supporting and protecting children, concern has been growing over the invasive nature of universalist policies that seek to use mass surveillance to intervene in family life (Waiton, 2016).

The central argument of this article is that neoliberalism requires an increase in the state's surveillance of the family and a lessening on the threshold for the state to involve itself in the life of the family. These changes allow the neoliberal state the opportunity to pursue its economic goals safe in the knowledge that it has adequate provisions in place to identify and work with families who threaten its hegemony. Using the mechanisms available to the state, opportunities exist to negate such a threat, while ensuring that those who pose a risk are swiftly and effectively dealt with. This article will explore the potential for the named person scheme to fulfil this role in a manner that causes services such as social work to be recast into new modalities that constitute a flight from the profession's moral and ethical base as an agent of social change.

\section{GIRFEC: A historical context}

To provide a clear historical narrative of the development of Scottish childcare policy it is important to foreground this article with an exploration of the context of the development of child welfare policy in Scotland. A notable addition in relation to children and families was the Children's (Scotland) Act 1995 which continued to promote the rights of the child in law and policy. This Act strengthened the requirements for the views of children to be taken into account as well as presenting a series of essential principles that reflect and legitimise a shift away from the welfarist principle to a more individualised conceptualisation of the interaction between the state and families. These principles include: each child who can form a view on matters affecting him or her has the right to express those views if he or she so wishes; parents should normally be responsible for the upbringing of their children and should share this responsibility; each child has a right to protection from all forms of abuse, neglect or exploitation; so far as is consistent with safeguarding and promoting the child's welfare, the public authority should promote the upbringing of children by their families; any intervention by a public authority in the life of a child must be properly justified and should be supported by all services from all relevant agencies working in collaboration (Children (Scotland) Act 1995).

Although the Act retains some emphasis on the welfare of the child, a more individualised narrative emerges, one that represents a shift toward the child being seen in a more individualised milieu. While on the surface this might seem superficial, as Clark and Smith (1998) perceptively point out; it is a significant signal shift in the direction of travel for services. The concept of welfare retains a symbolic association with a social work, where the philosophy of social pedagogy (central to Kilbrandon) is retained by promoting a holistic exploration of the influences of the social political and cultural environment. Wellbeing indicates 
a new direction; one more suited to a neoliberal environment where connections between environment and behaviour are underemphasised which leads to a revision of the relationship between the state and the family (Parton, 2005).

The Children and Young People Scotland Act received assent in 2014. A more powerful sense of a uniquely Scottish discourse emerges in this Act, one that continues the thread of the 1995 Act, which encouraged a more personalised approach to children and their families. There are two specific aspects of the 2014 Act that further enhance the directional shift towards a neoliberal policy paradigm that was prevalent in the 1995 Act. One of these is the emergence of the named person scheme, while the other is the introduction of the concept of wellbeing.

The notion of wellbeing encompasses a shift to a more individualised, personalised set of concerns associated with the vague concept of personal welfare. One outcome is that the concept of the person becomes foregrounded. As Esposito (2012) remarks, human life is considered untouchable only when based on personhood. The legal sphere and the pursuit of subjective rights in the name of the person are linked to the qualification of personhood. The result of this is an erosion of services emphasising collectivist notions of shared experience and belonging. The collective sense of experience is eroded and a newer more individualised notion that emphasises the concept of personhood replaces it. Because of this social work comes to represent individual change and development as opposed to wider societal, ecological or structural change. Esposito's (2012), critique of the sovereignty of the person is transposed and then it is embodied as named. The named person is a further qualification as to whether someone counts as a particular type of person and depends on an attitude towards and stance adopted towards that person.

The named person is not only a rational being but the stance taken towards them is inevitably a moral position (Dennet, 1988). In the Act, children from birth to the age of 18 would have a named person appointed in respect of them to work alongside the parents or carers of the children, should they require support and signposting. The named person is associated with a broader drive to ensure a more effective and streamlined array of services coordinated via a single planning process that would encourage and strengthen existing co-working arrangements across local authorities and their partner agencies. I will return to the operational issues of the named person scheme later in this article.

The scheme mobilises universal state involvement in the life of the family using the spurious notion that all children require a direct link to services which is provided by a particular professional who acts in the child's best interest. The scheme relies on each child meeting a series of wellbeing indicators (of which there are over two hundred) which are used as an indication of the child's development. The emphasis on the wellbeing indicators and the individual child so prominent in the scheme represents what Wacquant (2009) describes as a "moral individualism" that is a requirement of hegemonic societies as an "ongoing, routine feature of neoliberalism”. (p.310)

Foucault (2001) argued that governmentality was the "ensemble formed by the institutions, procedures, analyses and reflections the calculations and tactics that allow the specific, albeit complex form of power" (p.211). In applying this concept to GIRFEC, we see how this policy is just such an ensemble. The institutions of the Scottish state including charities, churches and social organisations have fully engaged with GIRFEC and have ensured it is prominent in all arenas. A national practice model has been developed by the Scottish government and comes with the possibility of further action should families demonstrate a lack of compliance, one which allows the state to engage with families in a more direct and potentially more punitive 
manner. This is particularly prescient for social workers as their involvement has the possibility of engaging with families who may demonstrate a lack of compliance for a variety of reasons often relating to a sense of isolation or vulnerability. In these circumstances, there is an opportunity for the state to move to a position of compulsory involvement to exert the complex form of power described by Foucault.

Parton (2005) deploys a Foucauldian analysis using the notion of discourse to frame social policy relating to children. The discourse established in GIRFEC affords the concept of personal wellbeing primacy. Although not ignored, the role of the wider societal impacts on children is firmly in the background with the practices associated with this (such as community development or welfare rights) becoming an adjunct and losing their position of importance and the symbolic value that centrality brings. The focus of the lens rests on individual children and the pressure of working in mainstream social work, often dominated by child protection concerns, ensures that it remains so.

The named person scheme is an increasingly pervasive regime of social regulation (Parton, 2005). The scheme mobilises and universalises the scope of state involvement while lowering the threshold for this involvement. This mobilisation, universalisation, and alteration of thresholds for involvement is mirrored by the increasing neoliberal direction of society. Neoliberal hegemony needs to develop an array of mechanisms to protect itself from potential insurgency or any threat to its dominance. As Hall (2013) cited in Evans and Giroux (2015 p.28) states:

Neoliberalism's victory has depended on the boldness and ambition of global capital, on its confidence that it can govern not just the economy but the whole of social life. On the back of revamped liberal political and economic theory, its champions have constructed a vision and a new common sense that have permeated society.... They have thoroughly undermined the redistributive egalitarian consensus that underpinned the welfare state, with painful consequences for vulnerable groups.

Here I argue that this alteration of thresholds for intervention is a deliberate and necessary requirement of neoliberal societies and is scaffolded by panoptic surveillance of families (Stoddart, 2015). Using Deleuze (1992) and the concept of The society of control I will argue that the named person scheme can be located as a method of social surveillance specific to a neoliberal context. The implications of which will be most seriously felt by those who are experiencing marginality, poverty and those families for whom the state already has a significant degree of involvement in their life.

\section{GIRFEC in a globalised neoliberal environment}

Stoddart (2015) explores GIRFEC and the named person as a paradigm for the surveillance of children. He argues that this policy is predicated on the state widening its involvement in the private lives of the family using state actors to gather and store information on families. Parton (2005) demonstrates how social workers become agents in the surveillance of children with some children experiencing greater surveillance than others. The move towards a neoliberal society requires the state to widen its surveillance to a universal provision allowing the state to infiltrate the life of every family. Families themselves now become concerning regardless of the presence or otherwise of particular actions or behaviours that are reasons for the involvement of the state. The emerging narrative, captured in various national and international legislation, is one of risky, troubled, feral families (Beddoe, 2014), often living in social housing and claiming state benefits. Noticeably absent from this narrative is any detailed consideration of the 
global impact that neoliberalism has had on the most vulnerable.

Parton (2005) describes this social climate as one of late modernity. He analyses this concept by comparing the death of two children who died thirty years apart in the United Kingdom. Maria Colwell was a white child from a predominantly white working class area who was beaten to death by her stepfather, while Victoria Climbie was a black child murdered by her Great Aunt and her partner who were both African. The differences in the social circumstances of the two children are stark and as Parton explains, "are in relation to issues of identity and global mobility" (Parton, 2005 p.49).

Family members killed both children; the difference in their social circumstances provides a vivid metaphor for the transition of society from a period of modernity to late modernity. Friends and neighbours knew Maria Colwell and her family; they were part of the estate she lived in and the ethnic mix of her family, the community and the professional involved was from a white British background. These are the cultural and social norms of modernity; her background and history solidly fixed in a series of established and recognisable social and cultural idioms; the housing estate, the family, and the workplace. Maria's life was recognisable to families across Britain. Victoria Climbie's circumstances were markedly different, Victoria was from the Ivory Coast, living in London in a reconstituted family, not well known in the community and surrounded by a diverse racial, cultural personal and professional environment. Victoria, having moved from Africa, was transient, her identity and location were not fixed, her family situation was fluid. She had moved to England via France, was in the care of extended family in an anonymous part of London, and was living in temporary and precarious housing.

Parton (2005) argues that to develop systems that intervene in the lives of families responsively and effectively, we must first understand the nature of late modernity as an environment where social and cultural norms that we once understood through the prism of modernity are recast into new and more fluid formats. Late modern society is no longer to be readily understood using traditional social and cultural norms, as the power and influence of the family environments predominant in modernity (like the Church, the work place and the family unit), have had their power base eroded. This reorganisation of society requires a similar reorganisation of public services. The services for vulnerable children inspired by Kilbrandon and are no longer fit for the emerging society. The new challenge of creating services that are responsive to the new iteration of society has emerged, an iteration dominated by neoliberal constructs that emphasise management of populations for maximum economic benefit. The state has moved from a position of being the guardian of its children to become a guardian of neoliberalism. To do this effectively, the state has engaged in a detailed process of developing mechanisms of mass surveillance to detect potential risk to its hegemony. The increase in inspection and regulation regimes is further evidence of the advanced mechanisms developed by the state.

The dominance of free market economics over all other aspects of the state role has required the state to adapt its policies to support the burgeoning neo liberal order. In a late modern environment, the dominance of free market economics over the state is captured in the key principles of the named person scheme, through its universalism, its application to all environments, and its requirement for all professional compliance. To provide services in late modernity a complete coverage of this newly emerging society is required. The global dominance of neoliberalism has resulted in significant social and economic disparity between those who enjoy economic traction and those who do not (Gilbert, 2013). To initially protect, and then expand the power and influence that increased economic traction brings, the state must develop an apparatus that supports 
and promotes neoliberalism, a doctrine that Harvey (2007, p.33) describes as "the financialisation of everything". Gilbert (2013, p.9) elaborates noting:

Put simply, neo liberalism, from the moment of its inception, advocates a programme of deliberate intervention form the government to encourage particular types of entrepreneurial, competitive and commercial behaviour in its citizens, ultimately arguing for the management of populations with the aim of cultivating the types of individualistic, competitive, acquisitive and entrepreneurial behaviour which the liberal tradition has historically assumed to be the natural condition of civilised humanity.

Webb (2009) argues that the emphasis on neoliberal politics requires the state to develop services more akin to "a hyper rational processing system which is based on the administrative steering of front line practice from a risk regulation perspective" (p.212). Using the analogy of the actuary Webb depicts social workers as commodifiers of risk, who apply increasingly complex actuarially inspired devices to measure the risk families pose to the neoliberal order. The need for universalism assumes prominence as social workers need to be able to assess all risk represented by all families. The adherence to neoliberalism forces every society to develop universal policies such as the named person to act as a viewfinder to assess those most likely to provide a threat.

This universalisation of surveillance is supported and buttressed by the development of increasingly sophisticated internet technology systems (Garrett, 2005), increased integration of services and the development of fix narratives that are built around short term opportunities for families to get better, or else. Taken together these three areas represent the dominance of neoliberalism on current child welfare policy in Scotland.

\section{GIRFEC, surveillance and societies of control}

Deleuze's (1992) seminal paper "Postscripts on Societies of Control" offers another method of conceptualising societal changes using the metaphor of a shift from disciplinary societies to societies of control. Disciplinary societies are characterised by "vast spaces of enclosure" (Deleuze, 1992, p.3), where environments such as schools and factories act as a vehicle for the delivery of discipline. Because of the globalised, rhizomatic nature of the neoliberal economic system, these entities find themselves in decline requiring new societies of control to emerge. These new societies are referred to as corporations. The corporation is fluid, lacking in boundaries and structures and requires a new approach to the delivery of discipline. Into this vacuum that the named person is inserted, the universalisation of its coverage, its technocratic solutions and it dependence of the merging of services make it perfectly suited to the society of control. Control comes to resemble a spirit or a gas, ubiquitous in its rhizomatic nature. These societies are described as being in a state that is "undulatory, in orbit, in a continuous network" (Deleuze, 1992, p.4). As capital moves across traditional geographic boundaries and takes on the amorphity of entities such as Uber and Airbnb, new forms of control are required to facilitate the continuing growth of the free movement of capital. To protect the rhizomatic political order that neoliberalism represents the state requires the development of policies that are responsive and flexible to any potential threat to the order.

In order to deliver control to a more fluid population social work services align themselves to societies of control. There is no room for differentiation between services, they meld together to resemble a gas.

This form of control manifests itself in an increased emphasis on integration of services and on reducing silo working. This shift in emphasis from the specialist approach to the universalism of the named person is 
evident in the shift from welfare to wellbeing described by Clark and Smith, (2012). Here the state has universalised its rhizomatic ubiquity with wellbeing providing a conceptual expansion of the territory for state involvement and surveillance. This mandate legitimises State involvement while ensuring that all families fall under its ever present and ever expanding watchful eye. The integration of services is a requirement to recognise that in societies of control, risk is not static but mobile, fluid and evolving.

This shift in emphasis is reflected by changes to the working environment of social workers, the move to flexible and agile working practices which include greater flexibility to work from home and increased capacity to access computer systems using mobile devices which incurs a destabilising erosion of traditional spaces resulting in a diminution of strong relational based working practices. The move away from the office supports the development of a more individualised work pattern, one that continues the thread of individualisation so prominent in the named person policy. The shared space of the office permits the development of a culture that can offer comfort and encouragement and the opportunity to explore the challenges of the profession in a shared space. This is a significant and irrevocable paradigm shift in the culture of service delivery, motivated by the society of control. The reduction in environment and culture takes place alongside the increase in surveillance and the universalism of the named person. Here the need to create a protective environment for neoliberalism is built using legislation and policy to create spaces where mass surveillance thrives (Scottish Government, 2016a), and those who present a threat to the neoliberal hegemony can be swiftly identified and quickly enmeshed with the mechanisms of control represented by the state.

Early intervention services that emphasise prevention, diversion and inter agency working enjoy a positive reputation in social work in Scotland, speaking as they do to the strong historical lineage dating back to the Kilbrandon report. Preventative and diversionary methods that emphasise a close inter agency approach comes with the perception of being conducive to reducing the need for statutory involvement in the future and are perceived as approaches that allow families to avoid the statutory involvement of the state in their lives. Early intervention is valorised by its resemblance to traditional liberal forms of relationship-based practice encouraged by Ruch, (2005) and Trevithick, (2003). But, as Featherstone, Morris and White (2014) point out, this approach is not without significant ideological baggage shot through, as it is with powerful neoliberal rhetoric described as "a future-oriented project building on elements of social investment and moral underclass discourses. It incorporates an unforgiving approach to time and to parents - improve quickly or within the set time limits." (Featherstone, Morris \& White, 2014, p.1739)

Featherstone Morris and White (2014), also note that early intervention in this environment can often result in the state's surveillance assemblage becoming enmeshed with families at increasingly early points in the family life while crowding out possibilities to resolve issues themselves using their own organic strategies and mechanisms. The practice of information sharing has the effect of increasing families' exposure to the full gamut of state tutelary services for relatively minor issues at increasingly earlier intervention points (Stoddart, 2015). State involvement in family life becomes couched in a normalizing discourse that encourages an unquestioning approach from those in receipt of services.

The named person policy was developed to encourage a closer working relationship between agencies such as health, education and social work which involves sharing knowledge, skills and information the desire to do so is translated into a common linguistic parlance to represent a closer alignment of services with more effective and efficient 
relationships between them. The desire is to ensure that the various services including health, social work, education and the police remain in close contact by sharing knowledge, information and intelligence. The separation between the assistancial and the juridical (Donzelot, Deleuze, \& Robert, 1980) becomes obscured as the silos in which the services are housed meld together. The specific identity of services, are eroded as they merge meaning families situations are exposed to an amalgamation of what Wacquant (2009) describes as the left and right hand of the state. A redrawing of the settlement between the state and the family is taking place, one that favours the state and the reassembling of the state's apparatus to facilitate this change. This redrawing of the settlement between the state and the family is inextricably linked to the prevalence of neoliberalism and its diverse nodes of governmental control which seek to provide a closer relationship between the state and its citizens allowing the state to encourage behaviours that promote neoliberal values while at the same time reducing opportunities to create threat to the neoliberal hegemony. Legislation and policy become statutory instruments of oppression that facilitate the application of neoliberalism to the population and reduce the populations' capacity to challenge the existing political and social order.

\section{GIRFEC, the family and the state: a neoliberal direction?}

The named person scheme claims to provide a paradigm for Scottish society to work towards creating a shared vision for the growth and development of all Scotland's Children. In doing so professionals including social workers, teachers and health visitors assume a formal role in implementing state policy. Writing about the troubled families' scheme in England, Crossley, (2015) describes this using Wacquant's concept of state crafting as a primary tool in promoting a neoliberal political agenda represented in Scotland by the named person. The involvement in the state in all aspects of the family life represented by the named person and the development of large numbers of wellbeing indicators represent a clear indication of the state developing a form of hyper surveillance of its children and their families to fit the requirements of neoliberalism. The emphasis on the person, which runs through the legislation, encourages a continued direction of travel away from broader notions of collectivism. The universalism of the scheme will continue the flight from the influence of structural societal issues as a concern for families to the actions of individuals. Evans and Giroux, (2015, p.9) argue:

all traces of the broader structural forces producing a range of social problems such as widening inequality and mass poverty disappear. Under the regime of neoliberalism, individual responsibility becomes the only politics that matter and serves to blame those who are susceptible to larger systemic forces.

As social workers this flight should be treated with significant concern as it moves social workers into a position that resembles working on families rather than working with families. A further impact of this type of policy direction is the deliberate disconnection of social work from a broader role that would seek to influence inequalities in society and operate as agents of social change as opposed to agents of social control (Fergusson \& Woodward, 2009).

\section{Conclusion}

In the Scottish context, the named person scheme is a vehicle for neoliberal state control. In order to maintain the neoliberal hegemony, the state requires families to adhere to a series of carefully constructed rules. To facilitate this, it is vital that the state develops a clear apparatus that operates as the vehicle for normative compliance. The challenges that represented by the shift from modernity to late modernity require a new approach to public services, one that can deliver the discipline required to manage a disparate precariat (Standing, 2011). 
Despite its benign presentation, the named person scheme is a device that supports and maintains a pernicious political ideology responsible for the impoverishment and disenfranchisement of many for the advantage of the few. In this regard, the named person has aspects of the trojan horse providing a format for the delivery of discipline, control and punishment in Scottish society while supporting the ideology of neoliberalism.

\section{References}

Beddoe, L. (2014). Feral families, troubled families: The spectre of the underclass in New Zealand. New Zealand Sociology, 29(3), 51-68.

Brodie I., Nottingham C., \& Plunkett, S. (2008). A tale of two reports: Social work in Scotland from Social Work and the Community (1966) to Changing Lives (2006). British Journal of Social Work, 38(4), 697-715. doi: 10.1093/bjsw/bcn035.

Children and Young Persons Scotland; Presented to Parliament by the Secretary of State for Scotland by Command of Her Majesty April, 1964, Edinburgh HMSO (Kilbrandon). Retrieved from http://www.legislation.gov.uk/ asp/2014/8/pdfs_20140008-en.pdf.

Children (Scotland) Act 1995 Retrieved from http://www.legislation.gov.uk/ukpga/1995/36/contents.

Clark, C., \& Smith, M. (2012). Changing Lives: What is really changing for Scottish social work? European Journal of Social Work, 15(3), 313-330. doi.org/10.1080/13691457. 2010.543892.

Crossley, S. (2015). Realising the (troubled) family: Crafting the neoliberal state. Journal of Families, Relationships and Societies, 5(2), 263-279. doi: 10.1332/204674315x1 4326465757666 .

Deleuze, G. (1992). Postscript on the societies of control. October, (Winter 1992), 3-7.

Dennet, D. (1988). Conditions of personhood. In M. Goodman (Ed.) What is a person (1 $1^{\text {st }}$ ed., pp145-169) Clifton, NJ: Humana Press.

Donzelot, J., Deleuze, G., \& Robert (1980). The policing of families. London, England: Hutchinson.

Esposito, R. (2012). Third person: Politics of life and philosophy of the impersonal. Cambridge: Polity Press.

Evans, B., \& Giroux, H. (2015). Disposable futures: The seduction of violence in the age of spectacle. San Francisco, CA: City Lights Books.

Featherstone, B., Morris, K., \& White, S. (2013). A marriage made in hell: Early intervention meets child protection. British Journal of Social Work, 44(7), 1735 -1749. doi: 10.1093/bjsw/bct052

Ferguson, I., \& Woodward, R. (2009). Radical social work in practice: Making a difference. Bristol, UK: The Policy Press.

Foucault, M. (2001). Governmentality. In D. Faubion, James (Ed.), Power: The essential works of Michel Foucault 1954-1984. (1 ${ }^{\text {st }}$ ed., pp.201-223). New York NY: The New Press.

Gilbert, J. (2013). What kind of thing is neoliberalism? New Formations 80-81(1), 7-22. doi.org/10.3898/nEWF.80/81. Introductlon.2013.
Garrett, P. M. (2005). Social work's "electronic turn": Notes on the deployment of information and communication technologies in social work with children and families. Critical Social Policy, 25(4), 529-553. doi: 10.1177/0261018305057044.

Harvey, D. (2007). A brief history of neoliberalism. New York, NY: Oxford University Press.

McAra, L., \& McVie, S. (2007). Youth justice? The impact of system contact on patterns of desistance from offending European Journal of Criminology, 4(3), 315-345. doi: $10.1177 / 1477370807077186$.

McGhee, J., \& Waterhouse, L. (2010). Locked out of prevention? The identity of child and family-oriented social work in Scottish Post-Devolution policy. British Journal of Social Work, 41(6), 1088-1104. doi: 10.1093/ bjsw/bcq121.

Parton, Nigel. (2005). Safeguarding childhood: Early intervention and surveillance in a late modern society. Basingstoke, UK: Palgrave Macmillan.

Ruch, G. (2005). Relationship-based practice and reflective practice: Holistic approaches to contemporary child care social work. Child \& Family Social Work, 10(2), 111-123. doi: 10.1111/j.1365-2206.2005.00359.x.

Scottish Government (2016a). Using the My World Triangle (and where appropriate specialist assessments) to gather further information about the needs of the child or young person. Retrieved from http://www.gov.scot/Topics/People/Young-People/ gettingitright/national-practice-model/my-worldtriangle.

Scottish Government (2016b). What is a named person? Retrieved from http://www.gov.scot/Topics/People/ Young-People/gettingitright/named-person.

Scottish Government. (2016c).What is GIRFEC? Retrieved from http://www.gov.scot/Topics/People/Young-People/ gettingitright/what-is-girfec.

Smith, M., \& Whyte, B. (2008). Social education and social pedagogy: Reclaiming a Scottish tradition in social work. European Journal of Social Work, 11(1), 15-28 doi: 10.1080/13691450701357174.

Standing, G. (2011). The precariat: The new dangerous class. New York, London: Bloomsbury Academic.

Stoddart, E. (2015). The named person: Surveillance and the wellbeing of children and young people in Scotland. Journal of Surveillance and Society, 13(1), 102-115.

Trevithick, P. (2003). Effective relationship-based practice: A theoretical exploration. Journal of Social Work Practice, 17(2), 163-176. doi: 10.1080/026505302000145699.

Wacquant, L. (2009). Punishing the poor: The neoliberal government of social insecurity. Durham, NJ: Duke University Press.

Webb, S. (2009). Risk, governmentality and insurance: The actuarial recasting of social work. In $\mathrm{H}$. Otto., A. Polutta, \& H. Zeigher (Eds.) Evidence-based practice-Modernising the knowledge base of social work? (pp. 211-226).Farmington Hills MI: Barbara Budrich Publishers.

Waiton, S. (2016). Third way parenting and the creation of the "named person" in Scotland: The end of family privacy and autonomy? SAGE Open, Retrieved from http://sgo.sagepub.com/content/6/ $1 / 2158244016629525$. 